\title{
Colorectal Hyperplastic Polyp
}

National Cancer Institute

\section{Source}

National Cancer Institute. Colorectal Hyperplastic Polyp. NCI Thesaurus. Code C5682.

A serrated polypoid lesion that arises in the colon and rectum. It is usually found in the distant colon and it rarely produces symptoms. This group includes goblet cell rich, mucin poor, and microvesicular hyperplastic polyps. 